\title{
Technocratic Development Planning Policies
}

\author{
Abu Tjaija ${ }^{1}$, Muhammad Ahsan Samad ${ }^{1}$, Rachzief Eka Putra ${ }^{1}$ \\ abutjaiyauntad@gmail.com
}

Public Administration Study Program, Univeritas Tadulako. Palu, Indonesia

\begin{abstract}
The aim of this study is to explain development planning in the development phase. The study method used is a comprehensive type of qualitative study that relates to the paradigm used by Nazir to offer a simple description of the issues being examined and to perform interviews with informants. Using 2 metrics that relate to the principle established by William L. Collor, namely participatory technocratic and democratic growth planning, the findings illustrated a variety of issues. Technocratic planning in the construction phase is associated with planning, unilateral growth, and restrictions. Two aspects regarding neighborhood engagement will be addressed in participatory democratic preparation, namely at the village creation workshop, and while village creation is ongoing.
\end{abstract}

Keywords: Planning, Development, Participatory, Community Participation

Received: September 29, 2020

Received in Revised: October 7, 2020

Accepted: October 9, 2020

\section{Introduction}

In national growth, villages play an important role. Not only because certain Indonesians reside in villages, but also because villages play a significant role in establishing national unity. National construction is a collection of simultaneous projects that span all the lives of people (Anggraini et al., 2015). Development planning is a framework/checklist/framework for the execution of construction programs thus progress planning should be implementative and relevant which should be integrated in a master strategy to the degree that it does not resolve immediate relevance and is worthy of influencing the lives of the broader community at the same time. It will predict demands for improvement both internally and externally as well as gathered on the basis of actual evidence in the field in relation to a city as a policy area in order to improve the idea of regional development planning, all of which claim that development planning is intended to enable improvements to a better development path for a government community or the ecosystem in a society (Mustanir et al., 2019; Amir, 2020).

Application preparation is a long-term phase of capacity development for the region that involves reliable and detailed preparation. This preparation ensures that it must be capable of covering where, when and how to evolve in order to generate sustained economic and social development in the city (Hidayat, 2017).

Development planning is an early step of the construction phase as an intermediate stage, therefore development planning is a guidance / checklist / foundation for carrying out development activities, therefore development planning should be implementative and relevant and must be collected in a strategic plan in the way that the urgent impotence may not really control (Utomo, 2015). In order to accomplish successful objectives, growth preparation should not only be carried out on paper without seeing the truth in the ground, relevant evidence in the ground as a means of formulating solutions or decisions based on data and information that can be used as content to execute a set of actions or group tasks, both physically and mentally and spiritually Howlett, 2009; Prahati et al., 2017). The 
development planning mechanism in Indonesia that has been widely applied since the mid1980s uses a combination of a bottom up approach and a top down approach (Mufti et al., 2020).

Originally, progress was used to imply economic growth. When the economic output of the city is large enough, a city is deemed good in introducing creation. Thus, the output of civilization or the production of the nation per year is what is calculated (Susanti et al., 2019). Development is characterized as a continuous phase of growing the amount and efficiency of capital, according to the literature on development economics (Jun, 2003; Lacopetta, 2010; Pearce et al., 2013). Development is an orchestrated social mechanism, the core of which is social transition, and every year in Third World nations, culture or state efficiency, the social engineering paradigm of development happens on a wide scale (Mustainah et al., 2020). Creation is a sequence of events that take place in a sustainable manner and consisting of stages that are separate on the one side, but "pieces" of an infinite existence on the other side. Generally speaking, progress is a phase of continual transition towards a better condition centered on those criteria (Zainudin \& Sutjiatmi, 2018).

Development planning is the main task of development administration or management. planning is necessary because development needs are greater than the available resources. Through planning, it is hoped that development activities that are efficient and effective can provide optimal results for the nation in order to utilize available resources and develop existing potentials (Pradigda, 2017). Such the growth would at least incorporate all the features of growth in the design of a development strategy, in particular sustainable development, a development that is mindful of its environmental circumstances. The creation of villages is a national initiative that has been initiated since ancient times, seeking to reduce suffering and enhance the health of rural communities. Rural construction takes place in separate regions, structured into planning initiatives and ventures (Hudson, 2013). A summary of the different systems and services may be separated into classes of projects and programs. Village growth is a sequence of initiatives carried out in the village area that seek to increase the village community's quality of living and increase the community 's wellbeing with plans developed on the basis of deliberation within the village population.(Ahdi, 2015).

The development features that pay importance to different things that can be shown include: (1). Guaranteeing equality and right. A sustainable growth policy focused on an fair allocation of land resources and output inputs, equal opportunity for women, as well as economic equality for the sake of enhancing health. (2). Biodiversity respect. The foundation of environmental sustainability is this variety. This government has the promise that natural resources are still accessible for the current and the future in a sustainable manner. (3). Using an integrative methodology, since dynamic interactions between humans and their world will be made possible, both for the present and the future, by utilizing the process of that methodology. (4). To schedule the management and usage of capital that can sustain growth, use a long-term perspective. Therefore, services which, of course, are safe and can be utilized and used (Wahidin, 2017).

At the village level, the government understands the value of growth. The government has initiated numerous ways and initiatives to facilitate the acceleration of growth in rural areas, but the outcomes are still not important in improving the quality of life and well-being of the population (Uceng et al., 2019). Providing resources to engage or invest in growth preparation for the Labuan village population would have a beneficial effect on the progress of village creation. The annual planning framework for village growth is defined as an operation or operation carried out below at each point of the planning phase (Sulaiman et al., 2015). In Labuan Lelea area, Labuan sub-district, development planning takes into 
consideration the laws that have been laid down, so that the society is still interested in development planning. The village government of Labuan Lelea, Labuan District, Donggala Regency and all elements of society must be active in the development planning phase to achieve a planned village development.

Technocratic preparation, according to Suzzetta, is a design mechanism focused on evidence and assessments or the wishes of the population and technical workers, both trained entities who, while they do not practice it themselves, are prepared with the information who they ought to obtain an object that can not be used as a production sector (Soemarwi, 2017). Participatory democratic growth planning is a form of planning change including representatives of the society that are the focus of growth (Sapri et al., 2019; Negara, 2020). Since, according to the evidence in the sector, growth is focused on the desires of the community and really aims for citizen involvement in planning. The second strategy is supposed to have consequences in city planning that are in line with what is occurring in the area or in line with the degree in community needs when, in practice, the group explicitly communicates its expectations with the characteristics of Bottom Up for the needs of this system (Putra, 2018).

The preparation measures compiled on the local government 's program from the bottom and not from development are as follows: (1) Investigation is a mechanism in which common issues that arise in the neighborhood are defined, investigated, and gathered. Work here is not an intellectual task, but an operation that is part of an attempt to improve. (2) The problem's formulation is an early stage of the investigation 's findings.

Based on the language, involvement derives from the term "participate," engagement, which implies joining, joining, participating (Akhmaddhian \& Fathanudien, 2015). Menurut Dr. Made Pidarta, Partisipasi adalah "pelibatan seseorang atau beberapa orang dalam suatu kegiatan". Adapun partisipasi merupakan keterlibatan atau peran serta seseorang baik dilakukan secara individu maupun kelompok dalam suatu kegiatan tertentu (Husnawati et al., 2020). According to Scientist Keith Davis defines: "Participation can be defined as mental and emotional involvement of a person in a group situation wich incourages him to contribute to group goals and share responsibility in them (Yuliani \& Herminasari, 2017).

Participatory design is a form of organizing growth by including representatives of the society who are politicized as the focus of growth. Participatory training requires both (people) in trying to address the challenges encountered in order to obtain the requirements needed (Darwis \& Zulfan, 2018). Community involvement in development as community interest in growth, engagement in planning activities and engagement in the usage and appreciation of development outcomes (Sulistiyorini dkk., 2015). The aims and means must be treated as a unified entity in which an objective is directed at the needs of the citizens and it would be impossible to be confident that the formula would take the side of the group if it is designed without including the population. Participation of development group members, including preparation and delivery practices of development services / initiatives carried out in the local community (Hermawan \& Suryono, 2016).

Bryant and White observed that community engagement was promoted by (1) rural community growth programs that were planned quickly and easily controlled by the group; (2) civic organizations and entities capable of mobilizing and channeling community aspirations; and (3) growing society's position in creation. Via this platform for engagement, through approaching the aim of improving a better standard of life, community participants can benefit from each other by experience. What happens is a shift in awareness, skills and attitudes that can lead to development. (Idris et al., 2019). 
The definition of the value of community involvement in planning is in line with the view of Conyers (1982) Participation of the society in these diverse phases of transition can render the group more motivated and more robust in the face of change. Conversely, the society appears to be more contingent (dependent) on the change actors if the group is not interested in multiple stages of transition and only behaves actively in any adjustments expected by the change actors (for example, government agencies, non-government organizations, and the private sector) (Mulyadi, 2015). The reliance of community on the agents of transition would intensify if this continues continuously.

\section{Methods}

The technique of data collection is achieved by observation (observation), interview (interview), and recording. Data processing using a structured method of data collection allows it possible for analysts to draw conclusions. Based on the method of looking for and consistently compiling data derived from interviews, field observations, and other resources, data collection can be readily interpreted and the conclusions can be communicated with others. Data processing consists of three parallel operations, namely: reduction of data, interpretation of data, drawing assumptions/checking.

\section{Results and Discussion}

In national growth, villages play an important role. Not only because certain Indonesians reside in villages, but also because villages play a significant role in establishing national unity. National growth is a collection of simultaneous projects that span all the lives of individuals.

Development planning is a guideline/reference/basis for the implementation of development activities, therefore development planning should be implementative (can carry out) and applicable (can be applied) and need to be compiled in a strategic plan in the sense that it does not regulate urgent importance and is able to touch the life of the wider community at the same time. be able to anticipate demands for change both internally and externally as well as compiled based on real facts in the field in relation to a region as a development area so that the concept of regional development planning is formed, both of which state that development planning is meant to make changes towards a better development direction for a community the government or its environment in a certain area by utilizing or utilizing various existing resources and must have a comprehensive and complete orientation but adhere to the principle of priority.

At the village level, the government understands the value of growth. In order to accelerate the growth of rural areas, the government has adopted numerous ways and services, but the outcomes are still not important in enhancing the standard of life and the community's wellbeing.

Participation can be defined as mental/thought and emotional/feeling involvement of individual in a community circumstance who, in an attempt to accomplish his aims, allows him to contribute to the company and is therefore accountable for the company involved.

As for the concept of culture, culture implies association, etymologically. In Latin socius, it switches to a popular term meaning "all about social life." In terms of sociology, collective means, in vocabulary, a position for human social activity that often serves as a nursery and as a social being for the development of human society.

Providing resources to engage or invest in growth preparation for the Labuan village population would have a beneficial effect on the progress of village creation. The annual 
village development planning framework is defined as an activity or activities carried out at each point of the planning phase from below.

In Labuan Lelea area, Labuan sub-district, development planning takes into consideration the laws that have been laid down, so that the society is still interested in development planning. Implementation is an operation or execution of a strategy that has been thoroughly planned and executed in detail, typically after the preparation is deemed ready. Implementation will, in basic terms, imply implementation. Implementation must be enforced with a policy that sees community not just as an entity but also as a topic of growth capable of setting targets, managing resources and guiding a method of growth capable of setting objectives, controlling resources and guiding processes to increase their quality of life (Pasinringi et al., 2020).

Participation in taking rewards is inseparable from the consistency and quantity of production outcomes that can be obtained. In terms of consistency, a program 's performance can be marked by an improvement in production, and in terms of quantities, that will be determined by the ratio of the program 's progress, whether or not it is in line with the goals that have been established. The community will take advantage of the decided outcomes of village growth, so the community must engage in any government-made strategy. The rewards of this increase must be channeled and felt by the persons who engage and collaborate in it.

In order to run and support the programs that have been developed, Community engagement at this point takes the form of energy and resources. Participation of the Society in the execution of this creation must include all stakeholders, collaborate collectively and be accountable so that all the objectives designed and decided upon as a result of decisions will be planned appropriately. The village government must include the community in the village development programme, so the community will not only appreciate the growth outcomes, but the community is often interested in the phase of introducing progress. It is anticipated that the society can figure out if or not the execution of the expected growth will work according to the aim. Besides that, we hope that the realized progress will be sustained and strengthened in order to build an environment of togetherness and transparency.

The village government of Labuan Lelea, Labuan District, Donggala Regency and all elements of society must be active in the development planning phase to achieve a planned village development. Types of preparation for growth, such as the Medium Term Action Plan (RPJM) for the village and the Annual Work Plan (RKT).

\section{Planning Technocratic Development}

Village council leaders helped by the population in designing development decisions focused on analysis and research are arbitrarily carrying out technocratic development planning, such that the subsequent development planning remains in line with the desires and it is also distant from the people's aspirations and needs. Science approaches and mechanisms are utilized for planning using a technological perspective for organizations or work groups who are technically liable for growth planning. Planning is carried out by engaging all parties of growth using a participatory strategy.

Technocratic planning is a planning mechanism focused on evidence and findings from assessments or the desires of the population and trained personnel, according to Suzzetta (2007), all informed communities that, while they may not encounter it themselves, are prepared with the information they need to gather the need for an object that can not be used as a demand to produce growth (Ding dkk., 2017). 
"According to the Legislation of the Indonesian Government concerning the National Development Planning Scheme," technocratic preparation is carried out by an agency or work unit that is functionally responsible for it utilizing a technical process and structure.

There are some observations pertaining to unilateral growth and constraints in the context of executing development planning from the aforementioned interpretation. Whether the expertise or talents in the village are adequate or can be depended on for a sustainable development method, unilateral implementation may be carried out without including third parties. The village government can therefore not be rigid, though, and actually administer it without first disseminating it to the group, since it is assumed that friction may be created by the whole group and that the development scheme will not operate smoothly. In the meantime, the village government must first formulate a strategy to mitigate failures or challenges in the application of development plans, and must then decide what requirements must be fulfilled and must conform with the circumstances in the village such that the outcomes are acceptable, not just for the village government, but also for the whole rural population of Labuan Lelea. In addition, implementation plans should not only be collected, but the monitoring factor must also be included in the plans to discourage anomalies or irregularities throughout the development phase.

\section{Participatory Preparation for Political Progress}

A form of city planning including group representatives who are placed as the focus of growth is participatory democratic development planning. Since, according to the evidence in the sector, growth is focused on the desires of the community and really aims for citizen involvement in planning. In conjunction with what is occurring in the area or in compliance with the extent of community desires, the second approach is supposed to have development design outcomes since the group demonstrates its expectations for the need for this process explicitly from the Bottom Up characteristics.

There are some observations relevant to intervention, focused on the aforementioned description. Next, the village of Labuan Lelea is broken into pros and cons. This is attributed to insufficient community abilities, and this is a challenge that the village government is introducing in the growth process. That is why one of the most significant aspects in completing village planning projects is expertise. On the other side, however, some interviewees stated that group engagement was very high or above average at the product implementation level. Second, the interest of the Labuan Lelea village population was very strong from the attendance when carrying out the village musrembang, in other words, all those who were invited to attend the musrembang village were also present.

\section{Conclusion}

Based on the study findings that have been presented in the previous chapter. First, preparing for village growth is a very necessary first step, in line with the village's wishes, such that the community will advance. Application preparation is often something that should be utilized when carrying out village application as a checklist / comparison so that it does not operate randomly and so that fraud may not happen. And it is hoped that the village growth preparation will be carried out as planned by the population of the area. Second, architecture must respond unilaterally to the condition and circumstances in the community. If the community 's skills are not adequate, the village government may invite outsiders, such as government organizations or educators, to provide the community with socialization or instruction. However, the municipality must therefore socialize the construction policy that would be rolled out to the neighborhood through the municipality growth planning meeting and through stages up to the city. With this, it is hoped that good cooperation between the 
government of the village and the community would be established. Third, the village government's development planning should be able to minimize the barriers that cause the program to not run smoothly, and this is also linked to the quality of human resources. Therefore, in order not to trigger advantages and drawbacks, there must be an arrangement beforehand between the village government and the population, the village government and the BPD, and the village government and relevant agencies. Fourth, the group engagement, both when the village musrembang was organized, and when the development program was going, was very strong.

\section{References}

Ahdi, D. (2015). Perencanaan penanggulangan bencana melalui pendekatan manajemen risiko. Reformasi: Jurnal Ilmiah Ilmu Sosial dan Ilmu Politik, 5(1), 13-30.

Amir, A. (2020). Public Policy Implementation: Study on Educational Budgeting of Palopo. Journal La Sociale, 1(1), 5-11.

Akhmaddhian, S., \& Fathanudien, A. (2015). Partisipasi Masyarakat dalam Mewujudkan Kuningan sebagai Kabupaten Konservasi (Studi di Kabupaten Kuningan). UNIFIKASI: Jurnal Ilmu Hukum, 2(1).

Anggraini, Y., Yasir, A., \& Ridlwan, Z. (2015). Perbandingan Perencanaan Pembangunan Nasional Sebelum Dan Sesudah Amandemen Undang-Undang Dasar 1945. FIAT JUSTISIA: Jurnal Ilmu Hukum, 9(1).

Conyers, D. (1982). An introduction to social planning in the Third World. John Wiley \& Sons Incorporated.

Hermawan, Y., \& Suryono, Y. (2016). Partisipasi masyarakat dalam penyelenggaraan program-program pusat kegiatan belajar masyarakat Ngudi Kapinteran. JPPM (Jurnal Pendidikan Dan Pemberdayaan Masyarakat), 3(1), 97-108.

Hidayat, W. (2017). Perencanaan Pembangunan Daerah: Pendekatan Pertumbuhan Ekonomi, Disparitas Pendapatan dan Kemiskinan. UMMPress.

Howlett, M. (2009). Policy analytical capacity and evidence-based policy-making: Lessons from Canada. Canadian public administration, 52(2), 153-175.

Hudson, H. E. (2013). From rural village to global village: Telecommunications for development in the information age. Routledge.

Husnawati, H., Nasution, Z., \& Wahyuni, S. (2020). Hubungan Peran Kader dengan Partisipasi Orangtua dalam Pelaksanaan Kegiatan Bina Keluarga Balita di Desa Mangliawan Kecamatan Pakis Kabupaten Malang. Jurnal Pendidikan Nonformal, 15(1), 20-28.

Idris, M. H., Syahida, N. P., \& Ardyansyah, A. (2019). Upaya Pemerintahan Kabupaten Bima Dalam Melibatkan Masyarakat Membangun Wisata Lariti Di Kecamatan Sape Kabupaten Bima (Studi Kasus Pada Dinas Pariwisata Kabupaten Bima). JIAP (Jurnal Ilmu Administrasi Publik), 6(2), 139-151.

Jun, Z. (2003). Investment, investment efficiency, and economic growth in China. Journal of Asian Economics, 14(5), 713-734.

Lacopetta, M. (2010). Phases of economic development and the transitional dynamics of an innovation-education growth model. European Economic Review, 54(2), 317-330. 
Mufti, M. I., Kurnia, I., Karim, I., \& Samad, M. A. (2020). Evaluation on Community Empowerment Policy after Conflict Resolution (A Study of Sub District Development Program in Poso District). International Journal of Multicultural and Multireligious Understanding, 7(8), 16-25.

Mulyadi, M. (2015). Perubahan Sosial Masyarakat Agraris ke Masyarakat Industri dalam Pembangunan Masyarakat di Kecamatan Tamalate Kota Makassar. Jurnal Bina Praja: Journal of Home Affairs Governance, 7(4), 311-322.

Mustainah, M., Samad, M. A., \& Kusuma, E. Z. (2020). Apparatus Resources Development in The Regional Agency of The Palu City. International Journal of Multicultural and Multireligious Understanding, 233-237. https://doi.org/10.18415/ijmmu.v7i7.1793

Mustanir, A., Yasin, A., Irwan, I., \& Rusdi, M. (2019). Potret Irisan Bumi Desa Tonrong Rijang Dalam Transect Pada Perencanaan Pembangunan Partisipatif. MODERAT: Jurnal Ilmiah Ilmu Pemerintahan, 4(4), 1-14.

Negara, I. S. (2020). Socio-Cultural Change of Society Against Health in the Village of Panciro, Gowa Regency. Journal La Sociale, 1(1), 19-24.

Pasinringi, A., Samad, M. A., Alamsyah, M. N., \& Jeni. (2020). Public Health Policy in Donggala Regency. Technium Social Sciences Journal, 11(1), 1-12.

Pearce, D., Barbier, E., \& Markandya, A. (2013). Sustainable development: economics and environment in the Third World. Routledge.

Pradigda, E. A. (2017). Strategi Perencanaan Pembangunan Industri Berbasis Produk Unggulan Daerah, Studi pada Dinas Perindustrian dan Perdagangan Kabupaten Blitar. Jurnal Paradigma (JP), 5(3), 122-131.

Prahati, P., Zuhdi, S., \& Aguswan, A. (2017). Penyuluhan Penyusunan Rencana Pembangunan Desa Di Desa Kuapan Kecamatan Tambang Kabupaten Kampar. Dinamisia: Jurnal Pengabdian Kepada Masyarakat, 1(1).

Putra, A. H. (2018). Peran Umkm Dalam Pembangunan Dan Kesejahteraan Masyarakat Kabupaten Blora. Jurnal Analisa Sosiologi, 5(2).

Sapri, S., Mustanir, A., Ibrahim, M., Adnan, A. A., \& Wirfandi, W. (2019). Peranan Camat Dan Partisipasi Masyarakat Dalam Musyawarah Perencanaan Pembangunan Di Kecamatan Enrekang Kabupaten Enrekang. Moderat: Jurnal Ilmiah Ilmu Pemerintahan, 5(2), 33-48.

Soemarwi, V. W. S. (2017). Tinjauan Normatif-Empiris Asas Partisipatif dalam Perencanaan Pembangunan Kota: Normalisasi Kali Ciliwung di Bukit Duri. Jurnal Muara Ilmu Sosial, Humaniora, Dan Seni, 1(1), 232-239.

Sulaiman, A. I., Lubis, D. P., Susanto, D., \& Purnaningsih, N. (2015). Komunikasi Stakeholder dalam Musyawarah Perencanaan Pembangunan (Musrenbang). MIMBAR: Jurnal Sosial dan Pembangunan, 31(2), 367-378.

Susanti, A., Kasmad, R., \& Waris, I. (2019). Mewujudkan Komitmen Organisasi. Journal of Public Administration and Government, 1(1), 1-8.

Uceng, A., Erfina, E., Mustanir, A., \& Sukri, S. (2019). Partisipasi Masyarakat Dalam Musyawarah Perencanaan Pembangunan Di Desa Betao Riase Kecamatan Pitu Riawa Kabupaten Sidenreng Rappang. MODERAT: Jurnal Ilmiah Ilmu Pemerintahan, 5(2), 18-32. 
Utomo, S. J. (2015). Implementasi Kebijakan Anggaran Pendapatan dan Belanja Desa (APBDes) Untuk Meningkatkan Pembangunan Desa (Studi Kasus di Desa Bandung Kecamatan Gedeg Kabupaten Mojokerto). Media Trend, 10(1), 19-31.

Wahidin, U. (2017). Peran Budaya Organisasi Pendidikan Islam dalam Menghadapi Tantangan Pembangunan Masyarakat, Negara dan Bangsa. Edukasi Islami: Jurnal Pendidikan Islam, 2(04).

Yuliani, S., \& Herminasari, N. S. (2017). Partisipasi Masyarakat Dalam Pengelolaan Hutan Mangrove Di Desa Segarajaya, Kecamatan Tarumajaya Kabupaten Bekasi. Jurnal Green Growth Dan Manajemen Lingkungan, 6(2), 42-53.

Zainudin, A., \& Sutjiatmi, S. (2018). Pembangunan dan Mekanisme Sistem Perencanaan (Studi Kasus Desa Pengabean dan Desa Karanganyar). JIP (Jurnal Ilmu Pemerintahan) : Kajian Ilmu Pemerintahan Dan Politik Daerah, 3(1), 1-14. 